\title{
Addendum \\ Addendum: Rudasill, K.M.; et al. Promoting Higher Quality Teacher-Child Relationships: The INSIGHTS Intervention in Rural Schools. Int. J. Environ. Res. Public Health 2020, 17, 9371
}

Kathleen Moritz Rudasill 1,*(D), Ray E. Reichenberg ${ }^{2}$, Jungwon Eum ${ }^{2}$, Jentry Stoneman Barrett ${ }^{2} \mathbb{D}$, Yuenjung Joo ${ }^{2}$, Emily Wilson ${ }^{2}$ and Martinique Sealy ${ }^{1}$

check for

updates

Citation: Rudasill, K.M.

Reichenberg, R.E.; Eum, J.; Barrett,

J.S.; Joo, Y.; Wilson, E.; Sealy, M.

Addendum: Rudasill, K.M.; et al.

Promoting Higher Quality

Teacher-Child Relationships: The INSIGHTS Intervention in Rural

Schools. Int. J. Environ. Res. Public Health 2020, 17, 9371. Int. J. Environ.

Res. Public Health 2021, 18, 3519.

https: / / doi.org/10.3390/

ijerph18073519

Received: 23 March 2021

Accepted: 24 March 2021

Published: 29 March 2021

Publisher's Note: MDPI stays neutral with regard to jurisdictional claims in published maps and institutional affiliations.

Copyright: (c) 2021 by the authors Licensee MDPI, Basel, Switzerland. This article is an open access article distributed under the terms and conditions of the Creative Commons Attribution (CC BY) license (https:// creativecommons.org/licenses/by/ $4.0 /)$
Virginia Commonwealth University, Richmond, VA 23284, USA; sealym@mymail.vcu.edu

2 University of Nebraska-Lincoln, Lincoln, NE 68588, USA; rreichenberg@unl.edu (R.E.R.); jeum@unl.edu (J.E.); jbarrett3@unl.edu (J.S.B.); joo9240@huskers.unl.edu (Y.J.); emily.wilson@huskers.unl.edu (E.W.)

* Correspondence: kmrudasill@vcu.edu

The authors wish to make the following correction to this paper [1]:

The original version of our article (Rudasill, K.M.; et al. Promoting Higher Quality Teacher-Child Relationships: The INSIGHTS Intervention in Rural Schools. 2020, 17, 9371) did not include the complete funding acknowledgement. The authors wish to change the information in the Funding section from:

Funding: This research was funded by the United States Institute of Education Sciences, grant number R305A180290.

to:

Funding: The research reported here was supported by the Institute of Education Sciences, U.S. Department of Education, through grant R305A180290, to the University of Nebraska-Lincoln. The opinions expressed are those of the authors and do not represent views of the Institute or the U.S. Department of Education.

The authors apologize for any inconvenience.

\section{Reference}

1. Rudasill, K.M.; Reichenberg, R.E.; Eum, J.; Barrett, J.S.; Joo, Y.; Wilson, E.; Sealy, M. Promoting Higher Quality Teacher-Child Relationships: The INSIGHTS Intervention in Rural Schools. Int. J. Environ. Res. Public Health 2020, 17, 9371. [CrossRef] [PubMed] 